\title{
Autoregulation of central and peripheral growth hormone receptor mRNA in domestic fowl
}

\author{
K L Hull and S Harvey \\ Department of Physiology, University of Alberta, Edmonton, Alberta, Canada, T6G 2H7 \\ (Requests for offprints should be addressed to S Harvey)
}

\begin{abstract}
Growth hormone $(\mathrm{GH})$ regulates numerous cellular functions in many different tissues. A common receptor is believed to mediate these tissue-specific effects, suggesting that post-receptor signalling molecules or tissue sensitivity to GH may differ between tissues. Tissue sensitivity depends upon the abundance of $\mathrm{GH}$ receptors (GHRs), thus tissue-specific GHR regulation could enable tissuespecific GH actions. The comparative autoregulation of GHR gene transcription in central (whole brain or hypothalami) and peripheral (liver, bursa, spleen and thymus) tissues was therefore examined in domestic fowl. In all tissues, a $4.4 \mathrm{~kb}$ GHR gene transcript that encodes the full-length GHR was identified. The abundance of this transcript was inversely related to endogenous $\mathrm{GH}$ status; it was lower in males with high circulating concentrations of $\mathrm{GH}$ and higher in females with lower basal concentrations of plasma $\mathrm{GH}$. The abundance of this transcript was also rapidly downregulated in response to a
\end{abstract}

bolus systemic injection of recombinant chicken GH, designed to mimic an episodic burst of endogenous $\mathrm{GH}$ release. This autoregulatory response was observed within $2 \mathrm{~h}$ of $\mathrm{GH}$ administration and was of greater magnitude in the brain than in peripheral tissues. Intracerebroventricular injections of GH also downregulated GHR gene expression in the brain, although hepatic GHR transcripts were unaffected $24 \mathrm{~h}$ after central administration of GH. In contrast, the induction of hyposomatotropism by passive GH immunoneutralization increased the abundance of the GHR transcript in the thymus, but not in other central (brain) or peripheral (bursa, liver) tissues. GH is not the sole regulator of GHR abundance, however; hypersomatropism induced by hypothyroidism was associated with an increase in GHR mRNA. The expression of the GHR gene in the domestic fowl would thus appear to be autoregulated by $\mathrm{GH}$ in a tissue-specific way.

Journal of Endocrinology (1998) 156, 323-329

\section{Introduction}

Growth hormone (GH) regulates numerous cellular functions by binding to growth hormone receptors (GHRs) and activating intracellular signalling cascades (Herington 1994, Kelly et al. 1994). A common receptor is believed to mediate these tissue-specific effects, suggesting that postreceptor signalling molecules or tissue sensitivity to $\mathrm{GH}$ may differ between tissues. Tissue sensitivity depends upon the abundance of GHRs, thus alterations in GHR gene transcription or translation could contribute to the specificity of $\mathrm{GH}$ action. GHR regulation by $\mathrm{GH}$ itself may be a particularly important determinant of $\mathrm{GH}$ action, as it would enhance or reduce the effect of a particular dose of $\mathrm{GH}$. The influence of chicken $\mathrm{GH}(\mathrm{cGH})$ on its receptor, however, remains controversial and unclear (Harvey \& Hull 1995).

In broiler fowl, hepatic GH-binding activity has been reported to be unaffected (Vanderpooten et al. 1991, Moellers \& Cogburn 1995) or downregulated (Vanderpooten et al. 1991, Moellers \& Cogburn 1995) by
GH administration, which reportedly has no effect on hepatic GHR gene expression (Cogburn et al. 1997). The abundance of hepatic GHR transcripts has also been shown to be inversely related to circulating concentrations of GH during ontogeny (Burnside \& Cogburn 1992). The relationship between $\mathrm{GH}$ and the GHR and the GHR gene may, however, depend on endogenous GH status, as hepatic GH-binding sites are downregulated by $\mathrm{GH}$ in hypophysectomized, but not in intact, birds (Vanderpooten et al. 1991). Similarly, other studies have demonstrated the downregulation of these sites in intact birds given intermittent injections, rather than continuous infusions of GH (Moellers \& Cogburn 1995). The influence of $\mathrm{GH}$ on hepatic GHR gene expression was therefore further evaluated in the present study, in birds with low circulating concentrations of $\mathrm{GH}$.

The liver is not the only target site for GH. Indeed, in the chicken, GHRs have recently been demonstrated in the central nervous system (Hull et al. 1993) and immune system (Hull et al. 1996c), suggesting novel roles for GH in neural and neuroendocrine function (Buntin \& Figge 
1989, Lea et al. 1990) and in cellular and humeral immunity (Marsh 1992, Hull et al. 1996a). These nonhepatic GHRs may also be dependent upon GH status, but may be regulated differently than the hepatic GHR. This possibility was first suggested by Frick et al. (1990), who showed that GHR mRNA was increased in rat muscle and liver, but decreased in fat, by hypophysectomy. Tissue differences in GHR autoregulation would enable a greater variation in tissue responses to the same $\mathrm{GH}$ bolus, thus augmenting the tissue specificity of $\mathrm{GH}$ action; however, the regulation of the GHR gene in non-hepatic sites has not been investigated. We have therefore examined the possibility that the abundance of neural and immune GHR transcript may be autoregulated, and compared this with the autoregulation of the hepatic GHR mRNA.

\section{Materials and Methods}

\section{Birds and tissues}

Adult White Leghorn chickens were used in most studies, as the abundance of hepatic GHR mRNA is upregulated during ontogeny and greatest in old birds with low circulating concentrations of GH (Harvey et al. 1991, Burnside \& Cogburn 1992); inhibitory effects of GH on GHR mRNA abundance would thus be readily detectable in tissues of adult fowl. The birds were killed by cervical dislocation, and central (whole brain, hypothalami or extrahypothalamic brain) and peripheral (liver, spleen bursa, or thymus) tissues were rapidly dissected out, frozen in liquid nitrogen and stored at $-80{ }^{\circ} \mathrm{C}$ until required for northern blot analysis.

\section{Influence of exogenous $\mathrm{GH}$}

Peripheral administration of GH In poultry, the secretion of $\mathrm{GH}$ is pulsatile, with an episode of $\mathrm{GH}$ release every 1.5-2 h (Vasilatos-Younken \& Zarkower 1987, Bacon et al. 1989). Hepatic GH-binding activity is decreased by pulsatile, but not continuous, administration of GH (Moellers \& Cogburn 1995). The possibility that a phasic increase in the circulating concentration of $\mathrm{GH}$ might autoregulate GHR gene expression in chickens was therefore examined, especially as hepatic GHR abundance and GHR gene expression in the rat are dynamically regulated by pulsatile episodes of pituitary $\mathrm{GH}$ secretion (Bick et al. 1992, Hull et al. 1996b).

Adult males ( $n=8$ per group) were injected i.m. with recombinant chicken GH (rcGH; Amgen, Thousand Oaks, California, USA) $(100 \mu \mathrm{g} / \mathrm{kg}$ body weight $)$ or with $0.9 \% \mathrm{w} / \mathrm{v} \mathrm{NaCl}$ vehicle $(1 \mathrm{ml} / \mathrm{kg})$ and tissues were collected $2 \mathrm{~h}$ later. The administration of GH by this route results in a rapid increase in circulating $\mathrm{GH}$, which peaks after $40 \mathrm{~min}$ and declines exponentially thereafter (Harvey
1993). For comparative purposes, tissues were similarly collected $2 \mathrm{~h}$ after $\mathrm{GH}$ administration from birds that had been injected with $\mathrm{GH}$ once daily for 14 days.

Intracerebroventricular administration of $\mathrm{GH}$ Because the GH gene is expressed in the brain, GHRs in neural tissues may be modulated by GH of pituitary and neural origin. The possibility that alterations in central GH status might differentially affect central or peripheral GHR transcripts was therefore examined by injecting 10 or $100 \mu \mathrm{g}$ ovine GH (oGH; NIADKD, Bethesda, MD, USA) $(n=6)$ or $0.9 \% \mathrm{w} / \mathrm{v}$ saline vehicle $(n=6)$ into the third cerebral ventricle of adult male White Leghorn chickens. Membrane binding sites for oGH have been demonstrated in the chicken hypothalamus (Attardo \& Harvey 1990) and similar intracerebroventricular (i.c.v.) injections of oGH have previously been shown to alter brain neurochemistry in domestic fowl (Lea \& Harvey 1993). The birds were killed after $24 \mathrm{~h}$ and the liver and brain extracted and quick-frozen in liquid nitrogen.

\section{Influence of endogenous $\mathrm{GH}$}

GH immunoneutralization The continous infusion of $\mathrm{GH}$ into young broilers does not reduce GH binding to hepatic sites (Moellers \& Cogburn 1995), possibly because their high endogenous concentrations of $\mathrm{GH}$ impair their sensitivity to exogenous GH. The effect of hyposomatotropism on GHR gene expression was therefore examined in rapidly growing White Leghorn chickens. [In rats, hepatic GHR gene expression is more sensitive to chronic than acute changes in GH status (Carmignac et al. 1993, Baumbach \& Bingham 1995).] Endogenous GH concentrations were reduced by passive GH immunoneutralization, which has previously been shown to induce growth retardation in rapidly growing birds (Scanes et al. 1977). Immature (5-week) chickens were injected i.m. daily for 10 days with a high-titre antiserum $(0.5 \mathrm{ml})$ raised against cGH (Harvey \& Scanes 1977) or with normal rabbit serum (NRS; $n=8$ per group) and the birds were killed $2 \mathrm{~h}$ after the last injection. The titre of the injected antibody was determined by its ability specifically to bind ${ }^{125}$ I-labelled cGH (Harvey \& Scanes 1977). The antibody had an affinity constant $\left(K_{\mathrm{a}}\right)$ of $3.5 \times 10^{-9} \mathrm{M}$ and a binding capacity of $6 \cdot 0 \times 10^{-8} \mathrm{M}$.

Hypothyroidism Endogenous concentrations of $\mathrm{GH}$ in chickens are markedly affected by thyroid status. Hypothyroidism, for instance, is a well-known stimulus for GH secretion (Harvey et al. 1988). The possibility that the induction of $\mathrm{GH}$ release in hypothyroid birds might downregulate tissue GH receptors was therefore examined. Adult male chickens were made hypothyroid by daily i.p. injections of thiourea $(50 \mathrm{mg} / \mathrm{kg})$, for 3 weeks. The birds were killed $2 \mathrm{~h}$ after the final injection and 
Hypothal.
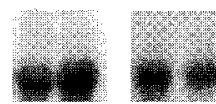

Liver

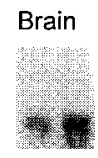

Burs

Thymus Spleen
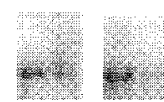

Figure 1 Northern blot analysis of GHR gene expression in chicken tissues. RNA moieties from liver, hypothalamus (hypothal.), extrahypothalamic brain (brain), bursa, and spleen are shown hybridized to a chicken GHR cDNA probe.

central and peripheral tissues were collected. Serum GH concentrations were determined by RIA (Harvey \& Scanes 1977).

Gender Endogenous concentrations of GH in the plasma of adult males are known to be greater than those in laying hens (Harvey et al. 1991). The possibility that male and female birds might differ in GHR gene expression was therefore examined and correlated with plasma $\mathrm{GH}$, as determined by RIA (Harvey \& Scanes 1977).

\section{Northern blot analysis}

Total cellular RNA was extracted from central and peripheral tissues using a commercial method, according to the manufacturer's instructions (RNA Now, Biocan Scientific, Mississauga, Ontario, Canada). In some studies, tissues from paired birds were pooled to facilitate analysis, especially as GHR abundance in non-hepatic tissues was expected to be low (Hull et al. 1993).

After extraction, the RNA was subjected to northern blot analysis as described previously (Render et al. 1995b), using a complementary DNA fragment (cGHR) (provided by Dr W Baumbach, American Cyanamid, Princeton, NJ, USA) encoding the majority of the coding region of the chicken GHR (cGHR). GHR mRNA content was quantified by laser densitometry and corrected for loading error by comparison with the hybridization of a GAPDH cDNA probe (provided by Dr W Baumbach). Autoradiograph exposure time was optimized for the RNA from each tissue and differences in transcript abundance between the different treatment groups were deter- mined by one-way ANOVA and the least significant difference test. Transcript abundance was not compared between different tissues, in view of these differences in autoradiographic exposure time.

\section{Results}

\section{Tissue GHR mRNA}

A major transcript of $4.4 \mathrm{~kb}$, hybridizing to the cGHR cDNA probe, was observed consistently in RNA extracted from liver, hypothalamus, extrahypothalamic brain regions, thymus, bursa and spleen (Fig. 1). Table 1 summarizes the changes in the abundance of this transcript in relation to the various factors tested. Smaller $1.0 \mathrm{~kb}$ and $2 \cdot 8 \mathrm{~kb}$ transcripts also hybridized with the GHR cDNA probe (data not shown). The abundance of these transcripts was not quantified, however, as their detection often required considerable overexposure of the autoradiograph.

\section{Influence of exogenous $\mathrm{GH}$}

The abundance of the hepatic $4.4 \mathrm{~kb}$ transcript was reduced by $25 \% 2 \mathrm{~h}$ after a single peripheral injection of cGH, compared with that in saline-injected chickens $(P<0 \cdot 001)$ (Fig. 2). GHR transcripts in the brain and spleen were also reduced in GH-treated birds $(P<0 \cdot 001)$, the magnitudes of the reductions $(40 \%$ in spleen, $60 \%$ in brain) being significantly greater $(P<0 \cdot 001)$ than those in the liver.

The abundance of the $4.4 \mathrm{~kb}$ GHR transcript in hypothalamic and extrahypothalamic tissues was similarly reduced (by 28\% $(P<0 \cdot 001)$ and 32\% $(P<0 \cdot 001)$ respectively) $2 \mathrm{~h}$ after the last GH injection in birds pretreated for 13 days with the same daily dose of cGH (Fig. 3). The mean reduction in whole brain (hypothalamic and extrahypothalamic) GHR mRNA was, however, less $(P<0 \cdot 001)$ than that in transcript abundance induced by a single GH injection. Moreover, whereas hepatic GHR mRNA was reduced after a single GH injection, it was unaffected after $\mathrm{GH}$ pretreatment (Fig. 3).

Table 1 Changes in GHR mRNA abundance in relation to various factors tested

\begin{tabular}{|c|c|c|c|c|c|c|}
\hline & \multicolumn{6}{|c|}{ GHR mRNA (\% control) } \\
\hline & Liver & Brain & Hypothal. & Spleen & Thymus & Bursa \\
\hline \multicolumn{7}{|l|}{ Treatment } \\
\hline $\mathrm{GH}(2 \mathrm{~h})$ & 75 & 60 & & 40 & & \\
\hline GH (14 days) & (NS) & 68 & 72 & & & \\
\hline $\mathrm{GH}$ (i.c.v.) & (NS) & 75 & & & & \\
\hline $\mathrm{GH}$ antiserum & (NS) & (NS) & & & 141 & (NS) \\
\hline Hypothyroid & 147 & 121 & & 111 & & \\
\hline Females (\% males) & 111 & 180 & & 133 & & \\
\hline
\end{tabular}




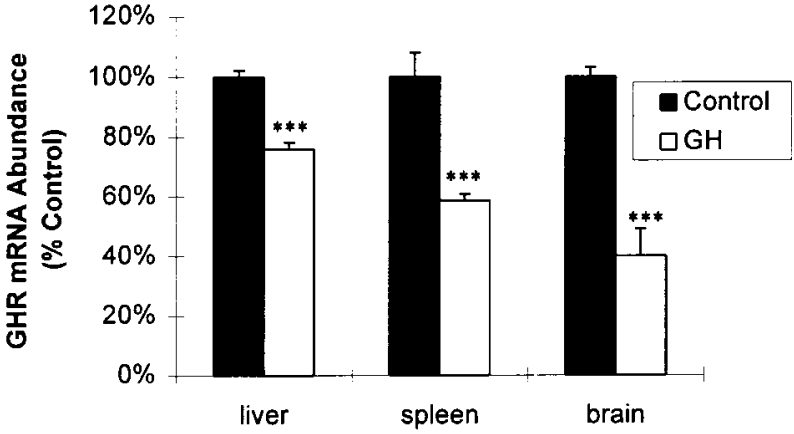

Figure 2 Abundance of the $4.4 \mathrm{~kb}$ GHR transcript in the liver, spleen and brain of chickens $2 \mathrm{~h}$ after an injection of $0.9 \%$ saline (Control, $\mathbf{\square}$ ) or rcGH (GH, $\square$ ). GHR mRNA abundance was quantified by laser densitometry and expressed relative to the abundance of GAPDH mRNA. To facilitate comparisons between tissues, data are presented as a percentage of control values (mean \pm S.E.M.). ${ }^{* *} P<0 \cdot 001$ compared with Control (ANOVA).

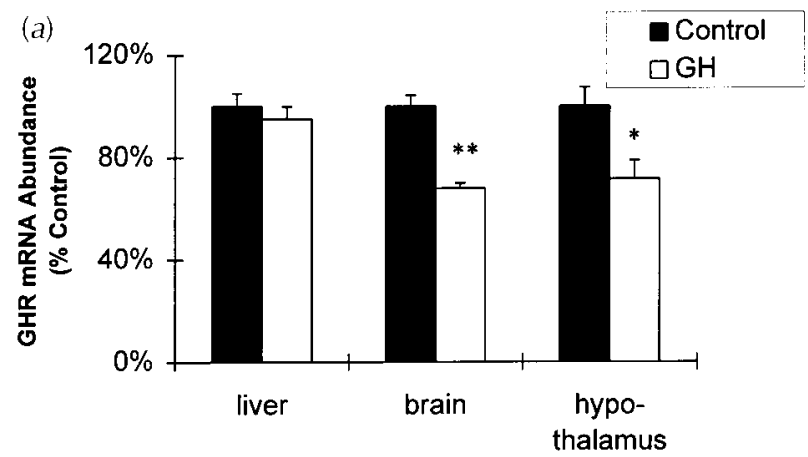

(b) hypothalamus liver $+\mathrm{GH}$ Control +GH Control

GHR mRNA
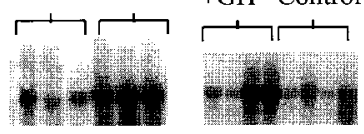

GHR mRNA

\section{GAPDH mRNA}
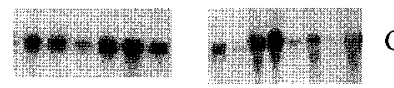

GAPDH mRNA

Figure 3 (a) The abundance of the $4.4 \mathrm{~kb}$ GHR transcript in the hypothalamus, extrahypothalamic brain (brain) and liver after 14 daily i.m. injections of $\mathrm{cGH}(\mathrm{GH}, \square)$ or $0.9 \%$ saline (Control, $\mathbf{\square}$ ). Birds were killed $2 \mathrm{~h}$ after the final injection. GHR mRNA abundance was quantified by laser densitometry and expressed relative to the abundance of GAPDH mRNA in arbitrary units. To facilitate comparisons between tissues, data are presented as a percentage of control values (mean \pm S.E.M.). ${ }^{\star} P<0 \cdot 05, P<0 \cdot 01$ compared with Control (ANOVA). (b) Northern blots of liver (four selected lanes for each treatment group) and hypothalamus (three lanes for each treatment group, each consisting of two or three pooled hypothalami), for illustrative purposes.

The abundance of the brain $4 \cdot 4 \mathrm{~kb}$ GHR transcript was also reduced $(P<0 \cdot 05) 24 \mathrm{~h}$ after the i.c.v. injection of 10 or $100 \mu \mathrm{g} / \mathrm{kg} \mathrm{GH}$, but the abundance of the hepatic GHR transcript was unaffected in both groups (Fig. 4).

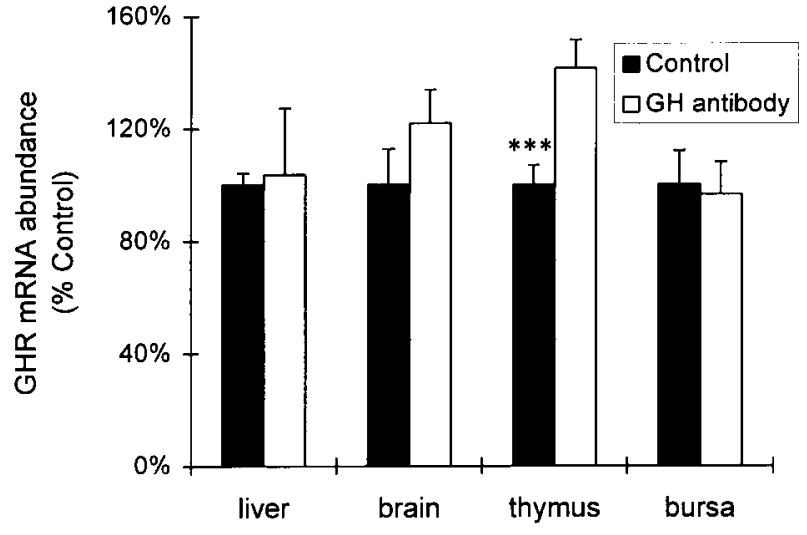

Figure 4 Abundance of the $4.4 \mathrm{~kb}$ GHR transcript in the liver, brain, bursa and thymus after five daily injections of a high-titre $\mathrm{GH}$ antiserum (GH antibody, $\square$ ) or of normal rabbit serum (Control, $\mathbf{0}$ ). GHR mRNA abundance was quantified by laser densitometry and expressed relative to the abundance of GAPDH mRNA in arbitrary units. To facilitate comparisons between tissues, data are presented as a percentage of control values (mean \pm S.E.M.). ${ }^{* \star} P<0 \cdot 001$ compared with antibody treated group (ANOVA)

\section{Influence of endogenous $G H$}

Daily administration of a high-titre $\mathrm{GH}$ antiserum $(\alpha \mathrm{GH})$ for 10 days reduced growth rate by $18 \%$ (body weight gain $175 \cdot 5 \pm 9 \cdot 4 \mathrm{~g}$ in NRS controls and $148 \pm 7 \cdot 8 \mathrm{~g}$ in $\alpha \mathrm{GH}$-treated birds; $P<0 \cdot 05)$. The ability of the antibody to immunoneutralize endogenous $\mathrm{GH}$ was demonstrated by the persistence of GH-binding activity in the serum from all the antibody-injected birds (whereas serum from NRS-treated birds did not bind labelled cGH, 50\% of the ${ }^{125} \mathrm{I}-\mathrm{cGH}$ tracer was bound with serum from the treated birds at final dilutions of $1: 128-1: 1024)$. However, while GH immunoneutralization resulted in a significant increase in GHR mRNA abundance in the thymus $(P<0 \cdot 001)$, it had no effect on GHR transcript abundance in the brain, liver or bursa (Fig. 5).

As expected, daily injections of PTU for 14 days induced hypothyroidism, as indicated by thyroid enlargement in thiourea-treated birds (thyroid weight $0.400 \pm 0.023 \mathrm{~g}$ ) compared with saline-treated birds $(0 \cdot 240 \pm 0 \cdot 011 \mathrm{~g}$; $P<0 \cdot 001)$ and chronically increased $(P<0 \cdot 01)$ circulating concentrations of $\mathrm{GH} \quad(12.6 \pm 2.4 \mu \mathrm{g} / 1$ in controls; $20 \cdot 6 \pm 2 \cdot 4 \mu \mathrm{g} / 1$ in PTU-treated birds). The abundance of the $4.4 \mathrm{~kb}$ transcript was increased $(P<0.05)$ in hypothyroid birds in both central (brain) and peripheral (liver and spleen) tissues (Fig. 6).

Basal circulating concentrations of $\mathrm{GH}$ in adult male birds were increased compared with those in adult females (plasma GH 13.7 $\pm 1 \cdot 7 \mu \mathrm{g} / \mathrm{l}$ in males and $7 \cdot 8 \pm 1 \cdot 3 \mu \mathrm{g} / \mathrm{l}$ in females). The abundance of the major GHR transcript in male tissues was consistently $(P<0 \cdot 05$ or less) lower than in tissues from females (Fig. 7). The gender difference was particularly marked in the brain and spleen GHR mRNA, 


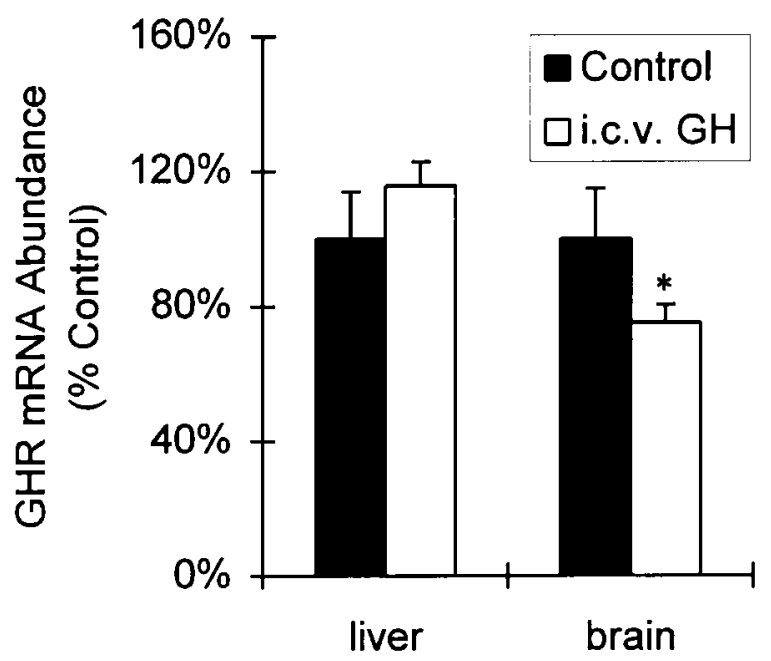

Figure 5 Abundance of the $4.4 \mathrm{~kb}$ GHR transcript in the brain and liver $24 \mathrm{~h}$ after a single injection into the third cerebral ventricle of cGH (i.c.v. GH, $\square$ ) (10 or $100 \mu \mathrm{g}$ ) or $0.9 \%$ saline (Control, $\mathbf{\square}$ ). Both doses of injected GH were equally effective; for clarity of presentation, the data from both groups are combined. GHR mRNA abundance was quantified by laser densitometry and expressed relative to the abundance of GAPDH mRNA in arbitrary units. To facilitate comparisons between tissues, data are presented as a percentage of control values (mean \pm S.E.M.). ${ }^{\star} P<0 \cdot 05$ compared with Control (ANOVA).

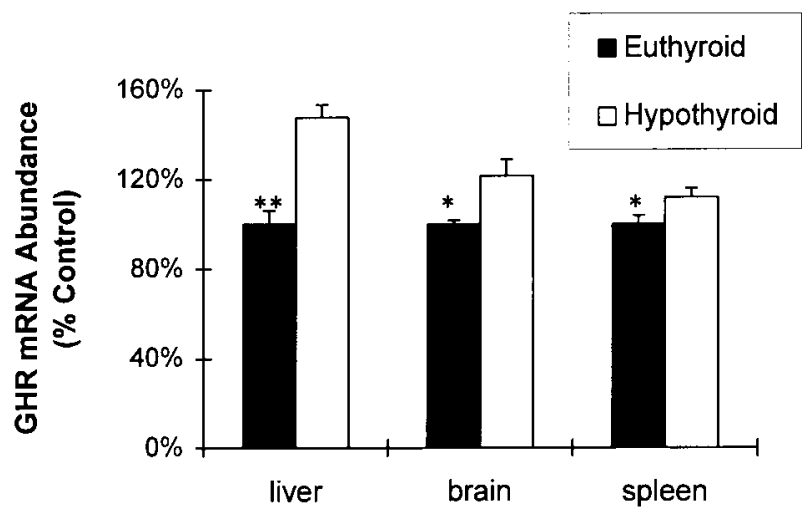

Figure 6 Abundance of the $4.4 \mathrm{~kb}$ GHR transcript in the liver, brain and spleen of euthyroid ( $\mathbf{\square}$ ) or hypothyroid $(\square)$ birds receiving daily injections of $0.9 \%(\mathrm{w} / \mathrm{v})$ saline or thiourea (respectively) for 21 days. GHR mRNA abundance was quantified by laser densitometry and expressed relative to the abundance of GAPDH mRNA in arbitrary units. To facilitate comparisons between tissues, data are presented as a percentage of control values (mean \pm S.E.M.). ${ }^{*} P<0 \cdot 05,{ }^{*} P<0 \cdot 01$ compared with Hypothyroid (ANOVA).

in which GHR transcript abundance in females was 180\% and $133 \%$, respectively, of that in males $(P<0 \cdot 001)$. In contrast, the abundance of the GHR mRNA in the livers of males was only $11 \%$ less than that in the livers of females, and the magnitude of the difference was less $(P<0.05)$ than the gender-related reduction in transcript abundance in the brain and spleen.

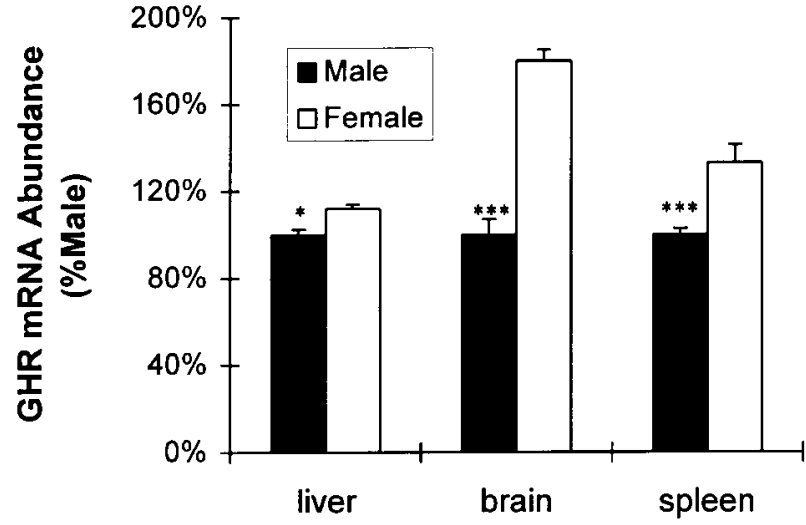

Figure 7 Relative abundance of the $4.4 \mathrm{~kb}$ and $2 \cdot 8 \mathrm{~kb}$ GHR transcripts in adult male ( $\boldsymbol{\square})$ and female $(\square)$ chickens. GHR mRNA abundance was quantified by laser densitometry and expressed relative to the abundance of GAPDH mRNA in arbitrary units. To facilitate comparisons between tissues, data are presented as a percentage of control values (mean \pm S.E.M.). ${ }^{*} P<0 \cdot 05,{ }^{* *} P<0 \cdot 001$ compared with females (ANOVA).

\section{Discussion}

These studies demonstrate, for the first time, that GH downregulates GHR gene transcripts in the brain, immune system and, to a lesser extent, the liver, of adult chickens. These results contrast with the findings of similar studies in rats, in which GHR mRNA abundance in these tissues was increased in response to a single exogenous GH bolus (Hull et al. 1996b). This tissue- and speciesspecificity of GHR mRNA autoregulation may enable $\mathrm{GH}$ to exert disparate, species- and tissue-specific cellular responses via a single class of GHR.

The abundance of hepatic GHR transcripts was decreased within $2 \mathrm{~h}$ after a single $\mathrm{GH}$ injection. In contrast, Cogburn et al. (1997) recently concluded that GHR gene expression in immature broiler fowl was insensitive to exogenous infusions or injections of GH. It is possible, however, that the lack of GHR autoregulation in that study was due to the high endogenous plasma concentration of GH and relatively low abundance of hepatic GHR mRNA in rapidly growing birds (Harvey et al. 1991, Burnside \& Cogburn 1992). Indeed, as endogenous GH secretion in adults is less than that in young birds, tissue GHR transcripts may be upregulated and therefore more sensitive to GH autoregulation. This possibility is supported by the ability of exogenous $\mathrm{GH}$ to downregulate GH-binding sites in hypophysectomized chicks, but not in intact chicks (Vanderpooten et al. 1991). Adult birds may therefore provide a better model than young birds for the assessment of GHR autoregulation.

The magnitude of GH-induced GHR mRNA downregulation was, interestingly, greater in tissues that synthesize GH (brain and immune tissues) than in the liver, which does not produce GH (Render et al. 1995a, b). For 
instance, chronic peripheral administration of $\mathrm{GH}$ resulted in a 38\% reduction in hypothalamic GHR mRNA, but only an $8 \%$ reduction in hepatic GHR mRNA. This enhanced sensitivity of central and immune GHRs to autoregulatory influences would suggest that $\mathrm{GH}$ has an important role in the these tissues, as high concentrations of GH would reduce GHR abundance and thus protect the tissue from excess GH stimulation. Inhibitory autoregulation of central GHRs may, for instance, protect the hypothalamus from excess GH-induced negative feedback (Lea et al. 1990), as somatostatinergic tone is increased (Harvey et al. 1990) and catecholamine synthesis is decreased (Harvey 1993, Lea \& Harvey 1993) in response to peripheral GH. Although factors regulating immune $\mathrm{GH}$ secretion have not been elucidated, similar mechanisms could occur in these tissues.

GH-induced GHR mRNA downregulation in central and immune tissues may also prevent excess activation of other GH-dependent processes. Immune GHRs may, for instance, mediate stimulatory GH effects on the growth and development of lymphoid organs (Marsh 1992) and cells (Haddad \& Mashaly 1991, Johnson et al. 1993). GH-induced GHR downregulation in the avian spleen and thymus may thus protect the animal from inappropriate or excess activation of the immune system.

Although GH could easily gain access to immune tissues, the mechanism by which peripheral GH alters brain receptors has not been elucidated in any species (Harvey et al. 1993). It is, however, becoming increasingly apparent that peripheral $\mathrm{GH}$ can gain access to the brain and alter the functioning of many brain regions, including the cerebral hemispheres (Lopez-Fernandez et al. 1996). GH may circumvent the blood-brain barrier via the choroid plexus or other circumventricular organs, as GHRs are present in the mammalian choroid plexus (Lai et al. 1991, Garcia-Aragon et al. 1992) and some, but not all, studies revealed uptake of radiolabelled GH from the periphery into the brain (Stern et al. 1976, Pacold et al. 1978, Hojvat 1982). Alternatively, GH may enter the brain from the pituitary gland, via retrograde transport up the hypophyseal stalk (Sato et al. 1989) or passage through the short pituitary portal vessels (Oliver et al. 1977). It is also possible that peripheral GH does not enter the brain, but acts via intermediary factors such as insulin-like growth factors (IGFs). This mechanism is not likely to have a major role, as IGF-I does not affect hepatic GHR expression in rats (Carmignac et al. 1993).

The possibility that GH may directly affect central GHRs is further supported by the ability of centrally injected GH to reduce brain GHR expression. Curiously, peripheral and central injections of $\mathrm{GH}$ stimulate and inhibit (respectively) central GHR expression in rats (Bennett et al. 1995). Bennett et al. (1995) suggested that this differential regulation of central GHRs by central and peripheral GH may represent the dose-dependent nature of GHR autoregulation; the greater concentration of i.c.v.-injected GH could be inhibitory, whereas the lower i.c.v. concentration resulting from peripheral injection could be stimulatory. In contrast, both central and peripheral injections of $\mathrm{GH}$ reduced brain concentrations of GHR mRNA in chickens. This may indicate a lesser degree of dose-dependency in chickens, or that peripheral GH may be affecting central GHRs by an indirect mechanism in mammals, but a direct mechanism in chickens.

Peripheral and central GHR expression would appear to be constitutively inhibited by normal concentrations of endogenous $\mathrm{GH}$, as GHR mRNA was more abundant in female chickens, which are hyposomatotrophic compared with male chickens. However, endocrine factors other than $\mathrm{GH}$ also have a determining role in $\mathrm{GH}$ transcript abundance. A decrease in circulating thyroid hormone status, for instance, increases GHR mRNA abundance, despite a parallel increase in circulating GH. GHR transcript regulation is thus complex and multifactorial.

In summary, GH causes a rapid and long-lasting reduction in GHR expression in central and peripheral tissues of the domestic fowl. This inhibitory interaction may result in some degree of GH resistance; thus strategies to increase receptor expression may be necessary to improve GH responsiveness in this species.

\section{Acknowledgements}

The authors would like to thank Dr W R Baumbach (American Cyanamid, Princeton, NJ) for the generous gift of the chicken GHR cDNA fragment. This work was supported by the Natural Sciences and Engineering Research Council of Canada.

\section{References}

Attardo D \& Harvey S 1990 Growth hormone-binding sites in chicken hypothalamus. Journal of Molecular Endocrinology 4 123-129.

Bacon L, Vasilatos-Younken R, Nestor KE, Anderson BJ \& Long DW 1989 Pulsatile patterns of plasma growth hormone in turkeys: effects of growth rate, age and sex. General and Comparative Endocrinology 75 417-426.

Baumbach WR \& Bingham B 1995 One class of growth hormone $(\mathrm{GH})$ receptor and binding protein messenger ribonucleic acid in rat liver, $\mathrm{GHR}_{1}$, is sexually dimorphic and regulated by $\mathrm{GH}$. Endocrinology 136 749-760.

Baumbach WR, Horner DL \& Logan JS 1989 The growth hormonebinding protein in rat serum is an alternatively spliced form of the rat growth hormone receptor. Genes and Development 3 1199-1205.

Bennett PA, Sophokleous S, Robinson ICAF \& Lightman SL 1995 Hypothalamic GH receptor gene expression in the rat: effects of altered GH status. Journal of Endocrinology 147 225-234.

Bick T, Hochberg Z, Amit T, Isaksson OGP \& Jansson JO 1992 Roles of pulsatility and continuity of growth hormone $(\mathrm{GH})$ administration in the regulation of hepatic GH-receptors, and circulating GH-binding protein and insulin-like growth factor-I. Endocrinology 131 423-429. 
Buntin F \& Figge GR 1989 Prolactin and growth hormone stimulate food intake in ring doves. Pharmacology, Biochemistry and Behaviour 31 533-540.

Burnside J \& Cogburn LA 1992 Developmental expression of hepatic growth hormone receptor and insulin-like growth factor-I messenger RNA in the chicken. Molecular and Cellular Endocrinology 89 91-96.

Carmignac DF, Robinson ICAF, Enberg B \& Norstedt G 1993 Growth hormone receptor regulation in growth hormone-deficient dwarf rats. Journal of Endocrinology 138 267-274.

Cogburn LA, Mao J \& Burnside J 1997 The Growth hormone receptor in growth and development. In Perspectives in Avian Endocrinology, pp 101-117. Eds S Harvey \& RJ Etches. Bristol: Journal of Endocrinology Ltd.

Frick GP, Leonard JL \& Goodman HM 1990 Effect of hypophysectomy on growth hormone receptor gene expression in rat tissues. Endocrinology 126 3076-3082.

Garcia-Aragon J, Lobie PE, Muscat GEO, Gobius KS, Norstedt G \& Waters MJ 1992 Prenatal expression of the growth hormone (GH) receptor/binding protein in the rat: a role for $\mathrm{GH}$ in embryonic and fetal development? Development 114 869-876.

Haddad EE \& Mashaly MM 1991 Chicken growth hormone, triiodothyronine and thyrotropin releasing hormone modulation of the levels of chicken natural cell-mediated cytotoxicity. Developmental and Comparative Immunology 15 65-72.

Harvey S 1993 Hypophysiotrophic control of GH secretion and its feedback regulation: an update. In Avian Endocrinology, pp 11-29. Ed P Sharp. Edinburgh: Journal of Endocrinology Ltd.

Harvey S \& Scanes CG 1977 Purification and radioimmunoassay of chicken growth hormone. Journal of Endocrinology 73 321-329.

Harvey S \& Hull KL 1995 Growth hormone action: receptors. In Growth Hormone, pp 303-337. Eds S Harvey, CG Scanes \& WH Daughaday. Boca Raton: CRC Press.

Harvey S, Scanes CG \& Klandorf H 1988 Thyrotropin-releasing hormone induces growth hormone secretion in adult hypothyroid fowl. General and Comparative Endocrinology 69 233-237.

Harvey S, Baidwan JS \& Attardo D 1990 Homologous and heterologous regulation of somatostatin binding sites on chicken adenohypophyseal membranes. Journal of Endocrinology 27 417-425.

Harvey S, Fraser RA \& Lea RW 1991 Growth hormone secretion in poultry. Critical Reviews in Poultry Biology 3 239-282.

Harvey S, Hull KL \& Fraser RA 1993 Growth hormone: neurocrine and neuroendocrine perspectives. Growth Regulation 3 1-11.

Herington AC 1994 New frontiers in the molecular mechanisms of growth hormone action. Molecular and Cellular Endocrinology 100 39-44.

Hojvat S 1982 Growth hormone immunoreactivity in the rodent and primate CNS; distribution, characterization, and presence posthypophysectomy. Brain Research 239 543-547.

Hull KL, Fraser RA, Marsh JA \& Harvey S 1993 Growth hormone receptor gene expression in sex-linked dwarf leghorn chickensevidence against a gene deletion. Journal of Endocrinology 137 91-98.

Hull KL, Janssens WCJ \& Harvey S 1996a Growth hormone: local actions in sites of synthesis. In Perspectives in Avian Endocrinology, pp 375-386. Eds S Harvey \& RJ Etches. Bristol: Journal of Endocrinology Ltd.

Hull KL, Lea RW \& Harvey S 1996 butoregulation of growth hormone receptor and growth hormone binding protein transcripts in central and peripheral tissues of the rat. Growth Regulation (In Press).

Hull KL, Thiagarajah A \& Harvey S 1996c Cellular localization of growth hormone receptors/binding proteins in immune tissues. Cell and Tissue Research 286 69-80.
Johnson BE, Scanes CG, King DB \& Marsh JA 1993 Effect of hypophysectomy and growth hormone on immune development in the domestic fowl. Developmental and Comparative Immunology 17 331-339.

Kelly PA, Goujon L, Sotiropoulos A, Dinerstein H, Esposito N, Edery M, Finidori J \& Postel-Vinay MC 1994 The GH receptor and signal transduction. Hormone Research 42 133-139.

Lai Z, Emnter M, Roos P \& Nyberg F 1991 Characterization of putative growth hormone receptors in human choroid plexus. Brain Research 546 222-226.

Lea RW \& Harvey S 1993 Growth hormone (GH) suppression of catecholamine turnover in the chicken hypothalamus - implications for GH autoregulation. Journal of Endocrinology 136 245-251.

Lea RW, Ahene CA, Marsh JA \& Harvey S 1990 Short-loop inhibition of thyrotropin-releasing hormone-induced growth hormone secretion in fowl. Journal of Endocrinology 126 237-244.

Lopez-Fernandez J, Sanchez-Franco F, Velasco B, Tolon RM, Pazos F \& Cacicedo L 1996 Growth hormone induces somatostatin and insulin-like growth factor I gene expression in the cerebral hemispheres of aging rats. Endocrinology 137 4384-4391.

Marsh JA 1992 Neuroendocrine-immune interactions in the avian species -a review. Poultry Science Reviews 4 129-167.

Moellers RF \& Cogburn LA 1995 Chronic intravenous infusion of chicken growth hormone increases body fat content of young broiler chickens. Comparative Biochemistry and Physiology, A $\mathbf{1 1 0}$ $47-56$.

Oliver C, Mical RS \& Porter JC 1977 Hypothalamic pituitary vasculature: evidence for retrograde blood flow in the pituitary stalk. Endocrinology 101 598-604.

Pacold ST, Kirsteins L, Hojvat S \& Lawrence AM 1978 Biologically active pituitary hormones in the rat amygdaloid nucleus. Science 199 804-806.

Render CL, Hull KL \& Harvey S 1995a Expression of the growth hormone gene in immune tissues. Endocrine 3 729-735.

Render CL, Hull KL \& Harvey S $1995 b$ Neural expression of the pituitary GH gene. Journal of Endocrinology 147 413-422.

Sato M, Chihara K, Kita T, Kashio Y, Okimura Y, Kitajima N \& Fujita T 1989 Physiological role of somatostatin mediated autofeedback regulation for growth hormone: importance of growth hormone in triggering somatostatin release during a trough period of pulsatile growth hormone release in conscious male rats. Neuroendocrinology 50 139-151.

Scanes CG, Harvey S \& Chadwick A 1977 Hormones and growth in poultry. In Growth and Poultry Meat Production, pp 79-85. Eds KN Boorman \& BJ Wilson. Edinburgh: British Poultry Science Ltd.

Stern WC, Miller M, Resnick O \& Morgane PJ 1976 Distribution of ${ }^{125}$ I-labelled rat growth hormone in regional brain areas and peripheral tissues of the rat. American Journal of Anatomy 144 503-508.

Vanderpooten A, Darras VM, Huybrechts LM, Rudas P, Decuypere E \& Kuhn ER 1991 Effect of hypophysectomy and acute administration of growth hormone $(\mathrm{GH})$ on $\mathrm{GH}-$ receptor binding in chick liver membranes. Journal of Endocrinology 129 275-281.

Vasilatos-Younken R \& Zarkower PG 1987 Age-related changes in plasma immunoreactive growth hormone secretory patterns in broiler pullets. Growth $\mathbf{5 1} 171-180$.

Received 24 March 1997

Revised manuscript received 13 June 1997

Accepted 9 September 1997 